\title{
Paecilomyces variotii as A Plant-Growth Promoter in Horticulture
}

\author{
Alejandro Moreno-Gavíra, Fernando Diánez ${ }^{\mathbb{D}}$, Brenda Sánchez-Montesinos and Mila Santos * \\ Departamento de Agronomía, Escuela Superior de Ingeniería, Universidad de Almería, 04120 Almería, Spain; \\ alejanmoga@gmail.com (A.M.-G.); fdianez@ual.es (F.D.); brensam@hotmail.com (B.S.-M.) \\ * Correspondence: msantos@ual.es; Tel.: +34-950-015511
}

Received: 1 April 2020; Accepted: 19 April 2020; Published: 22 April 2020

\begin{abstract}
In the present study, P. variotii, an endophytic fungus isolated from plant roots from the Cabo de Gata Natural Park (Parque Nacional Cabo de Gata-Spain), was tested to determine the effect on the growth promotion of tomato and pepper seeds and seedlings. For these purposes, germination trials in a laboratory and two experiments in a commercial nursery and greenhouse conditions were performed. The P. variotii isolate has shown a high ability to produce siderophores and IAA, but low ability to solubilize P. High values for germination percentage, seedling vigor, root and shoot length were obtained by $P$. variotii on tomato and pepper against control. $P$. variotii applications resulted in improved most of the growth parameters evaluated, for both horticultural crops, with the best results in the development of pepper seedlings. The application of a higher dose of $P$. variotii improved most of the morphological parameters and the Dickson quality index (DQI) value in tomato in seedlings and plants. The establishment of the endophytic fungus at the root enabled its biostimulant effects to persist after transplantation without any additional application. Few studies have analyzed this species as a biostimulant. The positive results from the tests showed its high potential. The application of this isolate can be of enormous benefit to horticultural crops for its high reproductive and establishment capacity.
\end{abstract}

Keywords: Paecilomyces; PGPF; tomato; pepper; plant probiotic microorganisms

\section{Introduction}

The genus Paecilomyces includes more than 100 species known for their multiple activities and habitat heterogeneity [1]. Among them, Byssochlamys spectabilis (Udagawa and Shoji Suzuki) Houbraken and Samson, formerly known as Paecilomyces variotii Bainier, is an ascomycete characterized by its ability to produce secondary metabolites, which belong to different chemical groups with wide biological activity [2-5]. This species has been described as a biological control agent (BCA) against nematodes [6,7], trematode eggs [8] and phytopathogenic fungi, such as Biscogniauxia mediterranea, Fusarium moniliforme and Phytophthora cinnamomi [9], Pyricularia oryzae [10], Fusarium graminearum [11] and Magnaphorte oryzae [12], among others, that function through their raw extracts, secondary bioactive metabolites or their mycelia. P. variotii produces metabolites with herbicidal [13] and insecticidal [14] activity and has been reported to control infections caused by pathogenic bacteria in fish [15] and humans [9]. In turn, this fungal species has even been shown to degrade aromatic compounds [16,17], in addition to removing ammonium from synthetic media and reducing ammonia emissions from chicken manure. [18]. However, it is also associated with many types of human infections in immunosuppressed patients [19]. Nevertheless, only studies related to the possible activity of these metabolites as a hormone-like substance or a promoter of phytohormone production by plant hosts have been published to date [20]. Very few references describe the application of $P$. variotii as a plant-growth promoter. The biocontrol agent ZhiNengCong (ZNC), which is an extract of $P$. variotii, is used in China [21]. ZNC is a 
highly effective plant elicitor that promotes plant growth by inducing auxin accumulation in root tips with low concentrations [21].

The use of plant probiotic microorganisms (PPMs) is an effective alternative to the use of chemical fertilizers [22-24]. The most studied PPMs are plant growth-promoting bacteria (PGPB), although there are numerous examples of plant growth-promoting fungi (PGPF), which increase crop yield [25-27]. Thus, the most relevant are those that establish endosymbiotic relationships, such as arbuscular mycorrhizal fungi, which solubilize nutrients, such as phosphorous, and micronutrients absorbed by plants [28-30]. Trichoderma is one of the most studied genera as PGPF [31], although many others fungi have demonstrated their potential growth-promoting capacity, such as Penicillium oxalicum [32], Penicillium simplicissimum [33], Fusarium oxysporum [34], Fusarium equiseti [35], Alternaria sp. [36], Aspergillus spp. [37] and Phoma [38], among others.

In the present study, P. variotii, an endophytic fungus isolated from plant roots from the Cabo de Gata Natural Park (Parque Nacional Cabo de Gata-Spain), was tested to evaluate: (a) the effects of seed priming with a fungus suspension on root colonization and tomato and pepper plant vigor; (b) the promotion of growth and quality of pepper and tomato seedlings under a conventional production system and (c) the effects of applying different doses to tomato seedlings and their subsequent transplantation in a greenhouse.

\section{Materials and Methods}

\subsection{Isolation of P. variotii from Plant Roots}

Twenty roots of different species of autochthonous plants from the Cabo de Gata Natural Park (CGNP; Almería, Spain) were collected for the isolation of fungal organisms in 2017. Collected samples were cleaned under running tap water to remove debris before use, air dried and processed for isolation of endophytic fungi. To remove epiphytic and surface-adhering microbes, the roots were cut into small, 2-3 cm long, pieces, were surface-sterilized with $2 \%$ sodium hypochlorite for $3 \mathrm{~min}$ and washed three times with sterile distilled water. The surface-sterilized samples were allowed to dry on sterile paper towels. Ten fragments from each root were placed onto potato dextrose agar (PDA, Difco) supplemented with $50 \mu \mathrm{g} \mathrm{mL}^{-1}$ chloramphenicol to suppress bacterial growth. After incubation at $25^{\circ} \mathrm{C}$ for $7 \mathrm{~d}$, individual hyphal tips of the developing fungal colonies were removed, placed on PDA medium and incubated for 5-7 d.

Colony morphology of the pure cultured isolates on PDA and conidiophore morphology were examined and identified by light microscopy, and all selected isolates were stored for further studies. Only one isolate, whose identification under a microscope was consistent with the genus Paecilomyces (Figure 1), was selected for this study (P. variotii CDG33). Molecular identification of the selected fungi was conducted following the procedure described by Diánez et al. [26]. The sequence was analyzed using a BLAST search in the GenBank database of the National Centre for Biotechnology Information (NCBI, http://blast.ncbi.nlm.nih.gov/Blast.cgi) and aligned to the nearest neighbors. The sequence has not been deposited in the GenBank database because the isolate is subject to patent.

The culture of $P$. variotii has been deposited in the CECT (Spanish Type Culture Collection, Valencia, Spain) with the collection number CECT 20957. This strain was selected for the experiments based on the results of a preliminary assay (data not shown). 


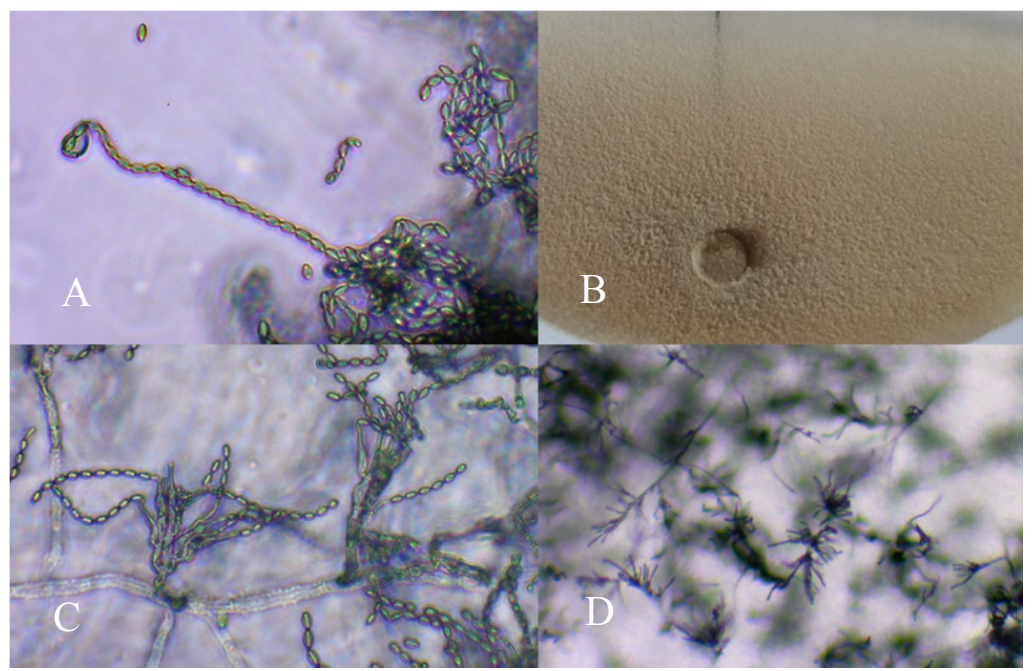

Figure 1. Conidiophore of Paecilomyces variotii (A: 400x; C: 200x; D: 100x) and an aspect of colony morphology (B) in the potato dextrose agar (PDA) medium.

\subsection{Analysis of Plant Growth-Promoting Attributes}

Siderophore production was determined on the chrome-azurol S (CAS) medium following the method of Schwyn and Neilands [39] and Louden et al. [40]. Fungal mycelial discs (5 mm) of active culture were transferred to CAS medium and orange halos around the colonies on blue were indicative of siderophore production. The diameter of the orange halo was measured at 24,48 and $72 \mathrm{~h}$.

Indole-3-acetic acid (IAA) production was estimated according to the procedure described by Diánez et al. [26]. P. variotii was grown in $50 \mathrm{~mL}$ of glucose peptone broth (GPB) amended with or without L-tryptophan (Sigma-Aldrich) at a concentration of $100 \mathrm{mg} \mathrm{L}^{-1}$. The flasks were inoculated and incubated on an orbital shaker at $150 \mathrm{rpm}$ at $25^{\circ} \mathrm{C}$ in the dark for $7 \mathrm{~d}$. After incubation, the suspension from each flask was centrifuged for $30 \mathrm{~min}$ at $12,000 \times \mathrm{g}$. The supernatant was filtered through sterile Millipore membranes (pore size $0.22 \mu \mathrm{m}$ ) and collected in sterile tubes. The culture supernatants $(3 \mathrm{~mL})$ were pipetted into test tubes, and $2 \mathrm{~mL}$ Salkowski reagent $\left(2 \mathrm{~mL}\right.$ of $0.5 \mathrm{~mol} \mathrm{~L}^{-1}$ $\mathrm{FeCl}_{3}+98 \mathrm{~mL}$ of $35 \% \mathrm{HClO}_{4}$ ) was added to it. The tubes containing the mixture were left for $30 \mathrm{~min}$ for red color development. The intensity of the color was determined by measuring the optical density at $530 \mathrm{~nm}$ using a scanning spectrophotometer. The quantity of IAA was determined by comparison with a standard curve for IAA. Five independent replicates of $P$. variotii were analyzed.

The qualitative evaluation of the phosphorus solubilized by $P$. variotii was performed using NBRIP and PVK media supplemented with $2 \%$ agar (Difco Laboratories, Detroit, MI, USA). Phosphate solubilization was detected by the formation of transparent zones surrounding fungal colonies in both media [41]. For the quantitative estimation of phosphate solubilization, a modified version of the procedure by Lima-Rivera [42] was followed. Flasks ( $250 \mathrm{~mL}$ capacity) containing $50 \mathrm{~mL}$ of NBRIP broth were inoculated with two disks of agar ( $5 \mathrm{~mm}$ diameter) that had been taken from pure cultures of $P$. variotii. Uninoculated flasks were used as a control (three replicates). Incubation was conducted at $26^{\circ} \mathrm{C}$ at a shaking speed of $100 \mathrm{rpm}$ for 3, 5, 7, 10 and $15 \mathrm{~d}$. Supernatants of each culture were analyzed for $\mathrm{pH}$ and phosphate concentration. Phosphates in culture supernatants were estimated using the Fiske and Subbarow method [43] and expressed as equivalent phosphate $\left(\mu \mathrm{g} \mathrm{mL}^{-1}\right)$. The experiments were conducted in triplicate and values were expressed as the mean. The total P in flasks was $10 \mathrm{mg} \mathrm{mL}^{-1}$.

\subsection{Mass Production of P. variotii on Solid Substrates}

A mixture of two kinds of substrates, buckwheat husk $(\mathrm{BH})$ and oat $(\mathrm{O})$, were tested for the mass multiplication of P. variotii. Different percentages $(90-10 \%, 80-20 \%$ and $70-30 \% v / v$ BH-O) of both 
substrates were submerged in different percentages of water $(10 \%, 20 \%$ and $30 \% v / v)$ for $24 \mathrm{~h}$. Each mixture was sterilized for $1 \mathrm{~h}$ at $125^{\circ} \mathrm{C}$ twice on consecutive days. Each mixture was placed on a tray and aseptically inoculated by spraying with $5 \mathrm{~mL}$ of spore suspension containing $4 \times 10^{6}$ spores $\mathrm{mL}^{-1}$ of $P$. variotii. The trays were kept at $25^{\circ} \mathrm{C}$ in the dark for $10 \mathrm{~d}$. In total, three samples $(2 \mathrm{~g})$ of the fungus-colonized substrate were removed from the trays in each treatment. The samples were successively diluted in sterile distilled water $+0.01 \%$ Tween $20^{\circledR}$ and the number of conidia $\mathrm{g}^{-1}$ of the solid substrate was quantified for each replicate using a Neubauer hemocytometer. There were three replications per treatment. The collected spores were used in the different experiments conducted in this study.

\subsection{Analysis of Effects of P. variotii on Seed Germination under Laboratory Conditions}

Seeds of tomatoes (Solanum lycopersicum 'Red Cherry') and pepper (Capsicum annuum 'Largo de Reus') were used in this study. The trial used a random block experimental design with two treatments (control and P. variotii) and four repetitions. Each repetition included 50 seeds that were germinated in Petri dishes (150 mm diameter) containing two sheets of Whatman No. 1 filter paper that were moistened with sterile distilled water. The seeds were surface-sterilized sterilized with $1.5 \%$ sodium hypochlorite $(\mathrm{NaOCl})$ for $5 \mathrm{~min}$, rinsed twice with sterile distilled water and dried under laminar airflow on sterile paper [26]. Treatments were performed by pipetting $50 \mu \mathrm{L}$ of P. variotii spore suspension $\left(1 \times 10^{5}\right.$ spores $\left.\mathrm{mL}^{-1}\right)$ or $50 \mu \mathrm{L}$ of water (control) on each seed; all boxes were placed in an incubator $\left(25 \pm 1{ }^{\circ} \mathrm{C}\right.$ in the dark). Root length $(\mathrm{mm})$ was measured from the tip of the primary root to the base of the hypocotyl. After 7 and $10 \mathrm{~d}$, for tomatoes and peppers, respectively, percent germination, root length and shoot length were recorded and a seed vigor index (SVI) was calculated as follows: SVI (length) = seed germination \% (mean root length + mean shoot length) [44].

\subsection{Analysis of Promoter Effects of P. variotii on Pepper and Tomato Seedlings: Experiment 1}

This experiment was performed in nursery polystyrene planting trays, each with 96 cells $(70 \mathrm{~mL}$ volume), at a commercial nursery (Almería Province, Spain). Pepper and tomato seeds red cherry and Largo de Reus, respectively, were sown into commercial peat mix and covered with vermiculite. After $2 \mathrm{~d}$ (tomato) and $4 \mathrm{~d}$ (pepper) in a germination room (relative humidity $(\mathrm{RH})=95 \% ; 25^{\circ} \mathrm{C}$ ), trays were located in a greenhouse and rinsed with water (control) or a $5 \mathrm{~mL}$ spore suspension per cell at $10^{5}$ spores per plant. Seedlings were grown using standard nursery culture conditions $\left(18-28^{\circ} \mathrm{C}\right.$; $75.4 \% \pm 6.7 \% \mathrm{RH})$ and four trays were used for each treatment. At $45 \mathrm{~d}$ after sowing, 20 plants per treatment and control were randomly selected from the four replications and measured for different growth parameters: number of leaves, stem length, stem base diameter, total leaf area and aerial and root dry weights. Leaf area was measured using the WINDIAS 3.1. (Delta-T Devices Ltd., Cambridge, UK, 2009) leaf area processing software. The Dickson quality index [45] was determined using the formula Dickson quality index (DQI) $=\mathrm{TDW} /((\mathrm{LS} / \mathrm{D})+\mathrm{SDW} / \mathrm{RDW}))$, where TDW is the total dry weight $(\mathrm{g})$, LS is the stem length $(\mathrm{cm}), \mathrm{D}$ is the stem diameter $(\mathrm{mm})$ and SDW and RDM are the stem and root dry weight (g), respectively. The experiments were conducted in autumn using a completely randomized design.

\subsection{Analysis of Effects of Applying Different Doses of P. variotii to Tomatoes: Experiment 2}

For this experiment, the procedure described in experiment 1 was followed. Three doses of P. variotii conidia (PaeD1: $10^{4}$ spores $\mathrm{mL}^{-1}$, PaeD2: $10^{5}$ spores $\mathrm{mL}^{-1}$ and PaeD3: $10^{6}$ spores $\mathrm{mL}^{-1}$ ) were applied to tomato seedlings growing under commercial plant nursery conditions with irrigation of the substrate, by adding $5 \mathrm{~mL}$ of spore suspension to each plant. The test was conducted in winter and four replicates were performed with 96 plants per replicate. The seedlings were harvested $30 \mathrm{~d}$ after sowing. Twenty plants per treatment and control were randomly selected from the four replicates and measured for the same parameters as described above. Another 25 plants from each treatment were transplanted into sandy soil in mid-February and analyzed in mid-May. The experiment was 
performed under greenhouse conditions (Figure 2). Water requirements were established according to climatic conditions and crop needs. Plants were fertilized with a commercial complex nutrient fertilizer.

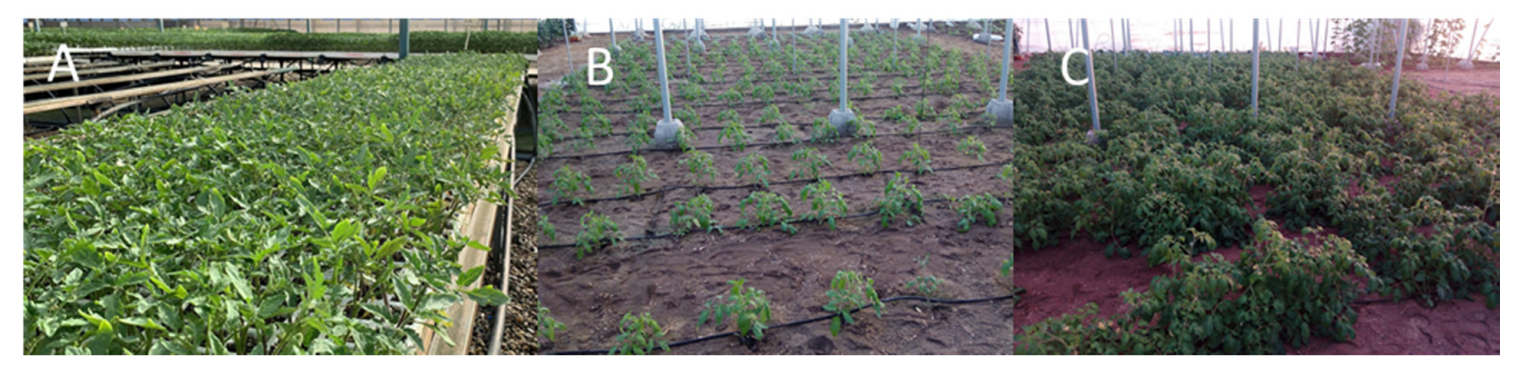

Figure 2. Tomato plants grown under commercial seedlings (A) and field assay, 30 (B) and 60 (C) days after transplanting.

In all tests (experiments 1 and 2), tomato and pepper roots inoculated with P. variotii were collected at the end of the tests. Roots were surface-sterilized in $0.1 \%$ sodium hypochlorite and washed with sterilized water. Lastly, $2 \mathrm{~cm}$ root fragments were placed in PDA medium to determine root colonization by the fungal isolate.

\subsection{Statistical Analysis}

Statistical analysis was conducted using Statgraphics Centurion XVIII Software. The data were tested by a one-way analysis of variance (ANOVA) or Student's $t$-test with significance defined as $p$ values less than $0.05(p<0.05)$. The experimental results are presented as the means and standard error $( \pm \mathrm{SE})$ for the different replicates. Mean separation was performed using Fisher's least significant difference (LSD) test.

\section{Results}

A total of 42 fungal isolates were obtained from the analyses of 20 root samples taken from plants native to the CGNP. All fungal isolates were obtained in pure cultures using standard techniques. The isolates were identified as filamentous fungi belonging to the phylum Ascomycota. The fungal isolates were identified to the genus level. Aspergillus, Trichoderma sp., Rustroemia sp. and Penicillium sp., were the most characteristic genera. They differed in color, type of conidiophore or presence of microsclerotia-like structures. Therefore were considered to be different. The presence of the genus Paecilomyces was especially relevant, and this genus was thus selected for this study (isolate CDG33). The amplified sequences of isolate of Paecilomyces were compared with available DNA sequences using BLAST, having 99\% homology with Paecilomyces variotii accession number JX282326.1.

\subsection{Mass Production of P. variotii on Solid Substrates}

The fungus multiplied well in all mixtures tested. Among the different treatments, whose composition varied in water content and the percentage of oats or buckwheat husk that were tested for mass multiplication of P. variotii, the proportion of 70\% $+30 \%$ for buckwheat husk and oats, respectively, with $20 \%$ water content, resulted in significantly higher spore production (Figure 3), followed by $90 \%+$ $10 \%$ with $10 \%$ water content (Table 1 ). The lowest spore production rate was observed at a percentage of $80 \%+20 \%$ with $10 \%$ water (Figure 3 ). 


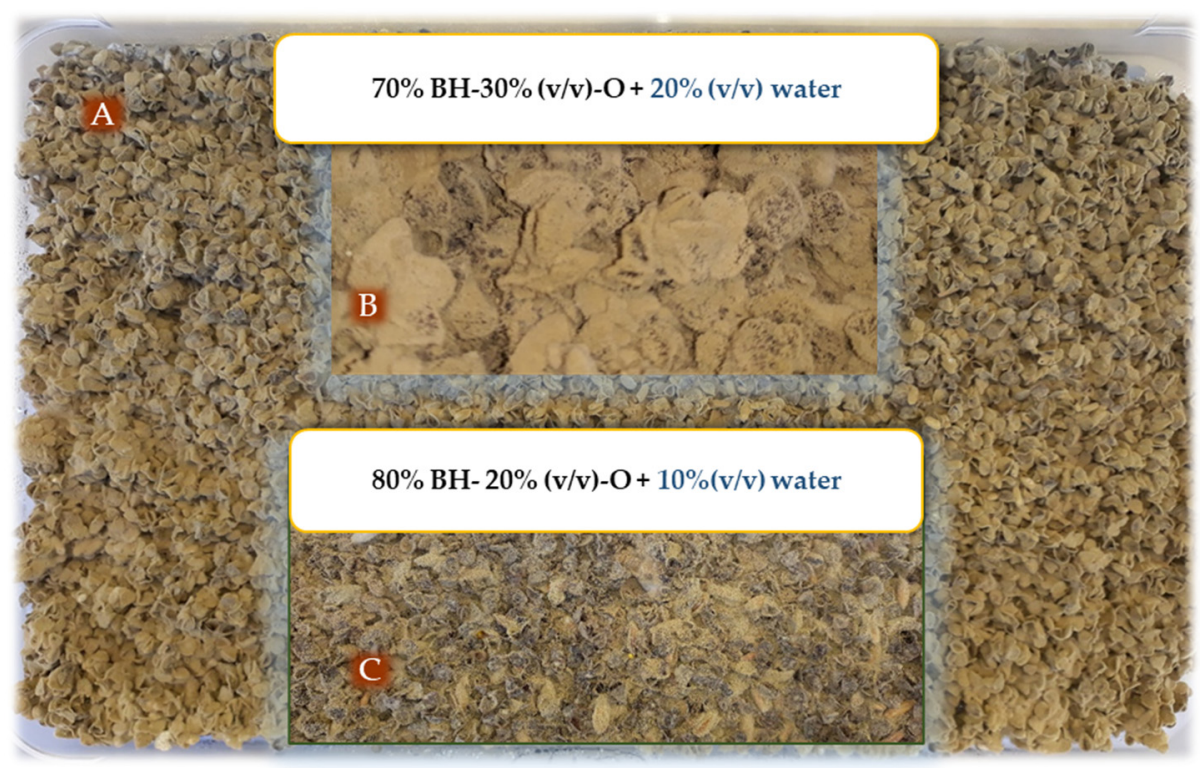

Figure 3. Mass production of $P$. variotii spores at a proportion of $70 \%+30 \%$ buckwheat husk and oats, respectively, $+20 \%$ water $(\mathbf{A}, \mathbf{B})$ and at $80 \%+20 \%$ with $10 \%$ water $(\mathbf{C})$.

Table 1. Effects of solid media on mass multiplication of $P$. variotii at varying substrates percentages $(v / v)$ and water contents $(v / v)$.

\begin{tabular}{|c|c|c|c|c|c|}
\hline \multicolumn{6}{|c|}{ Treatments } \\
\hline \multicolumn{6}{|c|}{$\%(v / v)$ water } \\
\hline \multicolumn{2}{|r|}{10} & \multicolumn{2}{|r|}{20} & \multicolumn{2}{|r|}{30} \\
\hline BH-O $\%$ & CFU.g ${ }^{-1}$ & BH-O $\%$ & $\mathrm{CFU} \mathrm{g}^{-1}$ & BH-O $\%$ & $\mathrm{CFU} \mathrm{g}^{-1}$ \\
\hline $90-10$ & $1.13 \times 10^{8} \pm 1.2 \times 10^{7} \mathrm{~b}$ & $90-10$ & $8.5 \times 10^{7} \pm 7.09 \times 10^{6} \mathrm{ef}$ & $90-10$ & $9.14 \times 10^{7} \pm 9.73 \times 10^{6} \mathrm{de}$ \\
\hline $80-20$ & $7.0 \times 10^{7} \pm 1.32 \times 10^{7} \mathrm{~g}$ & $80-20$ & $1.05 \times 10^{8} \pm 1.09 \times 10^{7} \mathrm{bc}$ & $80-20$ & $1.0 \times 10^{8} \pm 5.11 \times 10^{6} \mathrm{~d}$ \\
\hline $70-30$ & $8.04 \times 10^{7} \pm 1.14 \times 10^{7} \mathrm{f}$ & 70-30 & $1.24 \times 10^{8} \pm 1.06 \times 10^{7} \mathrm{a}$ & $70-30$ & $1.07 \times 10^{8} \pm 9.54 \times 10^{6} \mathrm{bc}$ \\
\hline
\end{tabular}

BH: buckwheat husk; O: oats. Data were analyzed by ANOVA and treatment means were compared according to Fisher's least significant difference (LSD) statistical procedure ( $F$-test at $p<0.05)$.

\subsection{Plant Growth-Promoting Characteristics of P. variotii: Siderophore Production, IAA and P Solubilization}

The formation of an orange-colored zone around the fungal colonies was observed, which indicated siderophore production by $P$. variotii (Figure $4 \mathrm{~A})$. The diameter of the halo $(\mathrm{mm})$ was estimated at $3.88 \pm 0.33,5.55 \pm 0.22$ and $8.83 \pm 1.29$ for 24,48 and $72 \mathrm{~h}$, respectively.

IAA was produced by $P$. variotii in medium supplemented with $100 \mathrm{mg} \mathrm{L}^{-1}$ tryptophan during a $7 \mathrm{~d}$ period, and the final concentration was $0.049 \pm 0.001 \mathrm{mg} \mathrm{mL}^{-1}$. The final concentration of IAA was $0.03 \pm 0.001 \mathrm{mg} \mathrm{mL}^{-1}$ in medium supplemented without tryptophan.

No halo of P solubilization by P. variotii was detected in any of the media used (NBRIP and PVK media supplemented with $2 \%$ agar). The effect of $P$. variotii on the soluble phosphate concentration is shown in Figure 4. The initial concentration of $P$ in the medium was used to quantify the concentration of $\mathrm{P}$ solubilized by $P$. variotii. As shown in Figure 4B, no P solubilization was detected during up to $15 \mathrm{~d}$ of incubation, assessing a soluble $\mathrm{P}$ of $2.01 \pm 0.68 \mathrm{~g} \mathrm{~L}^{-1}$ versus $0.74 \pm 0.25 \mathrm{in}$ the control $(p=0.0243)$. In turn, no change in the $\mathrm{pH}$ of the medium was detected, which remained at approximately 7. 

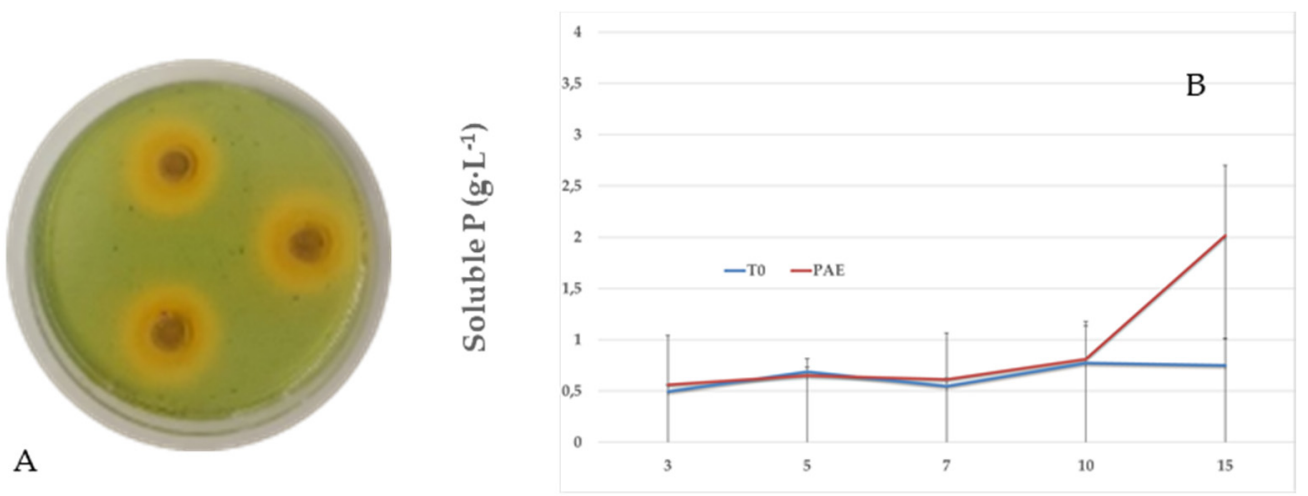

Days after inoculation

Figure 4. Formation of orange-colored halos owing to production of siderophores by P. variotii (A). Effects of $P$. variotii on phosphate solubilization (B) in NBRIP broth containing tribasic calcium phosphate $(10 \mathrm{~g})$. Mean standard deviation is expressed in error bar. The results are shown as the average of the three replicates, in $\mathrm{g} \mathrm{L}^{-1}$.

\subsection{P. variotii Inoculation Effects on Tomato and Pepper Seed Germination}

Table 2 outlines the results of the in vitro application of $P$. variotii to tomato and pepper seeds. Direct inoculation of seeds by $P$. variotii isolate spores had a significant effect $(p<0.05)$ on the percent seed germination, root and shoot length, and SVI in tomatoes. The increase in root and shoot length was $18.23 \%$ and $17.85 \%$, respectively. However, pepper seeds treated with $P$. variotii showed no improvement in SVI $(p>0.05)$.

Table 2. Effects of P. variotii isolate on tomato and pepper seed germination 7 and $10 \mathrm{~d}$ after treatment, respectively. pp

\begin{tabular}{ccccc}
\hline Treatment & \% Germination & Root Length $(\mathbf{c m})$ & Shoot Length $(\mathbf{c m})$ & Seed Vigor Index \\
\hline \multicolumn{5}{c}{ Pepper } \\
\hline $\boldsymbol{p}$-value & 0.5369 & 0.6162 & 0.0010 & 0.9975 \\
$\boldsymbol{P}$ variotii & $80 \pm 9.79$ & $2.37 \pm 1.30$ & $1.66 \pm 0.55$ & $323.00 \pm 127.07$ \\
T0 & $76 \pm 7.30$ & $2.26 \pm 1.24$ & $1.98 \pm 0.56$ & $322.93 \pm 119.36$ \\
\hline \multicolumn{5}{c}{ Tomato } \\
$\boldsymbol{p}$-value & 0.0020 & 0.0013 & 0.0036 & 0.0000 \\
To & $89 \pm 3.82$ & $4.41 \pm 1.33$ & $3.30 \pm 1.15$ & $686.70 \pm 210.40$ \\
\hline
\end{tabular}

T0: control without $P$. variotii. Data were analyzed using Student's $t$-test $(p<0.05)$.

\subsection{Promoter Effects of P. variotii Isolates on Tomato and Pepper Seedlings: Experiment 1}

The effects of P. variotii application on morphological parameters and DQI are shown in Table 3. Most of the growth parameters evaluated in tomato and pepper were improved by $P$. variotii, when compared with those of the experimental control, with the best results in the development of pepper seedlings.

These increases were statistically significant for most parameters. The increases assessed in pepper and tomato seedlings $(\mathrm{P} / \mathrm{T})$ were $9.7 \% / 6.9 \%$ for stem length, $4.9 \% / 0.8 \%$ for stem diameter, $10.6 \% / 6.0 \%$ for leaf number, $18.2-6.7 \%$ for root dry weight, $16.7 \% / 10.7 \%$ for aerial dry weight and $10.1 \% / 7.5 \%$ for leaf area. In tomatoes, $P$. variotii applications resulted in a decrease in root dry weight, albeit without significant differences from that of the control. P. variotii application improved plant quality, albeit without significant differences for tomato plants $(p=0.2059)$. In all tests (experiments 1 and 2$), P$. variotii was observed in tomato and pepper roots analyzed in PDA medium. 
Table 3. Morphological parameters and quality index of pepper and tomato seedlings treated with P. variotii isolate at $45 \mathrm{~d}$ after sowing.

\begin{tabular}{|c|c|c|c|c|c|c|c|}
\hline Treatment & $\begin{array}{l}\text { Length of } \\
\text { Stem }(\mathrm{cm})\end{array}$ & $\begin{array}{l}\text { Diameter } \\
(\mathrm{mm})\end{array}$ & $\begin{array}{l}\text { Number } \\
\text { of Leaves }\end{array}$ & $\begin{array}{l}\text { Areal Dry } \\
\text { Weight (g) }\end{array}$ & $\begin{array}{c}\text { Root Dry } \\
\text { Weight (g) }\end{array}$ & $\begin{array}{c}\text { Leaf Area } \\
\text { mm }^{2}\end{array}$ & DQI \\
\hline \multicolumn{8}{|c|}{ Pepper } \\
\hline$p$-value & 0.0000 & 0.0008 & 0.0000 & 0.0000 & 0.0022 & 0.0020 & 0.0054 \\
\hline P. variotii & $29.63 \pm 1.75$ & $3.83 \pm 0.21$ & $7.39 \pm 0.54$ & $0.42 \pm 0.05$ & $0.13 \pm 0.02$ & $83.58 \pm 11.27$ & $0.051 \pm 0.00$ \\
\hline T0 & $27.01 \pm 2.07$ & $3.65 \pm 0.23$ & $6.68 \pm 0.70$ & $0.36 \pm 0.04$ & $0.11 \pm 0.03$ & $75.88 \pm 11.15$ & $0.046 \pm 0.00$ \\
\hline \multicolumn{8}{|c|}{ Tomato } \\
\hline$p$-value & 0.0002 & 0.0039 & 0.0330 & 0.0042 & 0.1443 & 0.0397 & 0.2059 \\
\hline P. variotii & $27.37 \pm 2.06$ & $3.81 \pm 0.27$ & $4.40 \pm 0.54$ & $0.62 \pm 0.07$ & $0.14 \pm 0.02$ & $74.45 \pm 11.85$ & $0.067 \pm 0.01$ \\
\hline T0 & $25.61 \pm 2.07$ & $3.78 \pm 0.22$ & $4.15 \pm 0.48$ & $0.56 \pm 0.10$ & $0.15 \pm 0.02$ & $69.28 \pm 10.17$ & $0.063 \pm 0.01$ \\
\hline
\end{tabular}

T0: control without $P$. variotii. Data were analyzed using Student's $t$-test $(p<0.05)$.

\subsection{Effects of Dose of Application of P. variotii Isolates on Tomato Seedlings and Transplanted Plants:} Experiment 2

The effects of applying three doses on the development of tomato seedlings under commercial plant nursery conditions and subsequent transplantation into soil under greenhouse conditions are shown in Table 4. As shown in Table 4, applying different doses of P. variotii promoted seedling shoot development, significantly decreasing, in some cases, root development. The best results were assessed for dose 3, which resulted in a 30.2\% increase in stem length, 15.7\% in stem diameter, $19.5 \%$ in leaf number and $46.2 \%$ in aerial dry weight. However, root dry weight decreased $25.0 \%$. The decrease in root length can cause stress when transplanting tomato seedlings, thereby decreasing plant quality. The DQI [45] expresses the global aptitude of a plant to successfully overcome the transplantation phase, based on overall plant development, while considering the balance between plant shoots and roots. Higher values of this index indicate higher seeding quality. In this case, despite the decrease in root length, a higher value of this index was observed for dose 3 , with a significant difference for all doses tested, but not with the control treatment.

Table 4. Morphological parameters and Dickson quality index (DQI) of tomato seedlings (30 d after sowing) and plants (90 days after transplanting) treated with different doses $\left(10^{4}, 10^{5}\right.$ and $10^{6}$ spores per plant, (D1, D2 and D3, respectively) of P. variotii.

\begin{tabular}{|c|c|c|c|c|c|c|}
\hline \multicolumn{7}{|c|}{ Tomato seedling } \\
\hline Treatment & $\begin{array}{l}\text { Length of } \\
\text { stem }(\mathrm{cm})\end{array}$ & $\begin{array}{l}\text { Diameter } \\
(\mathrm{mm})\end{array}$ & $N^{o}$ leaves & $\begin{array}{c}\text { Areal dry } \\
\text { Weight (g) }\end{array}$ & $\begin{array}{c}\text { Root dry } \\
\text { Weight (g) }\end{array}$ & DQI \\
\hline$p$-value & 0.0000 & 0.0000 & 0.0002 & 0.0000 & 0.0028 & 0.0481 \\
\hline Pae D1 & $16.12 \pm 2.11 \mathrm{a}$ & $3.72 \pm 0.38 b$ & $3.58 \pm 0.53 b$ & $0.27 \pm 0.09 a$ & $0.039 \pm 0.01 a$ & $0.045 \pm 0.01 b$ \\
\hline Pae D2 & $14.46 \pm 2.58 b$ & $3.50 \pm 0.38 c$ & $3.71 \pm 0.84 \mathrm{ab}$ & $0.25 \pm 0.08 \mathrm{a}$ & $0.035 \pm 0.01 \mathrm{a}$ & $0.046 \pm 0.01 b$ \\
\hline Pae D3 & $16.27 \pm 3.05 a$ & $3.99 \pm 0.28 a$ & $3.93 \pm 0.78 \mathrm{a}$ & $0.38 \pm 0.09 a$ & $0.027 \pm 0.01 b$ & $0.054 \pm 0.01 \mathrm{a}$ \\
\hline T0 & $12.5 \pm 2.22 b$ & $3.45 \pm 0.36 c$ & $3.29 \pm 0.61 c$ & $0.25 \pm 0.08 b$ & $0.036 \pm 0.01 a$ & $0.045 \pm 0.01 b$ \\
\hline \multicolumn{7}{|c|}{ Tomato Plants } \\
\hline Treatment & $\begin{array}{l}\text { Length of } \\
\text { stem }(\mathrm{cm})\end{array}$ & $\begin{array}{l}\text { Diameter } \\
(\mathrm{mm})\end{array}$ & Internodes & $\begin{array}{c}\text { Areal dry } \\
\text { Weight (g) }\end{array}$ & $\begin{array}{c}\text { Root dry } \\
\text { Weight (g) }\end{array}$ & DQI \\
\hline$p$-value & 0.1876 & 0,1244 & 0.9759 & 0.0048 & 0.7796 & 0.0283 \\
\hline Pae D1 & $82.75 \pm 12.97 \mathrm{ab}$ & $11.57 \pm 1.08 \mathrm{ab}$ & $14.20 \pm 1.93 a$ & $50.67 \pm 10.80 \mathrm{a}$ & $4.22 \pm 1.20 \mathrm{a}$ & $24.84 \pm 7.68 \mathrm{a}$ \\
\hline Pae D2 & $87.20 \pm 9.42 \mathrm{a}$ & $11.59 \pm 1.02 \mathrm{ab}$ & $14.30 \pm 1.25 a$ & $49.19 \pm 10.21 a$ & $4.26 \pm 1.64 \mathrm{a}$ & $24.23 \pm 8.16 a$ \\
\hline Pae D3 & $77.60 \pm 7.75 b$ & $11.84 \pm 1.08 \mathrm{a}$ & $14.10 \pm 1.28 \mathrm{a}$ & $49.38 \pm 10.53 a$ & $4.20 \pm 1.37 a$ & $25.78 \pm 7.66 a$ \\
\hline T0 & $84.00 \pm 7.10 \mathrm{ab}$ & $10.58 \pm 0.91 b$ & $14.00 \pm 1.63 a$ & $39.13 \pm 7.99 b$ & $3.73 \pm 0.91 \mathrm{a}$ & $16.84 \pm 3.79 b$ \\
\hline
\end{tabular}

T0: control without $P$. variotii. Different letters indicate significant differences according to the one-way ANOVA test $(p=0.05)$. Treatment means were compared according to the Fisher's LSD statistical procedure $(F$-test at $p<0.05)$. 
Once transplanted in soil, the findings showed that the three doses favored several morphological parameters studied in the development of tomato plants in relation to those of control plants, with higher values for dry weights and DQI but without significant differences for the three doses tested. The establishment of the endophytic fungus at the root (Figure 5), therefore, enabled its effects to persist after transplantation.

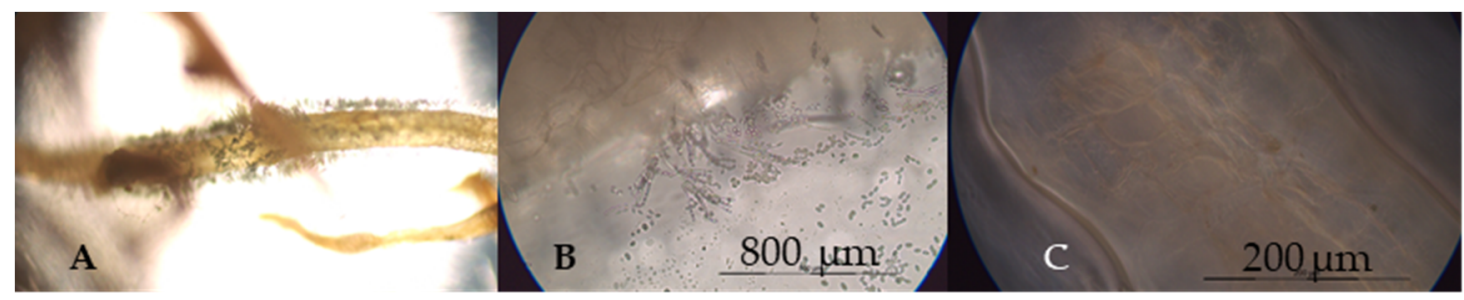

Figure 5. P. variotii mycelium and conidiophores colonizing tomato (A: $100 \times$; B: $200 \times$ ) and pepper roots (C: $400 \times)$.

\section{Discussion and Conclusions}

In this study, fungal isolates from surface-sterilized root segments of native plants and soil were collected from the CGNP. This park is located in an arid-to-semiarid Mediterranean region where the predominant fungi genera are Penicillium and Aspergillus, as well as isolates from the group termed Dark Septate Endophytic (DSE) fungi, which colonize plant roots. The DSE fungi isolated herein formed dark brownish microsclerotia-like structures. The role of DSE fungi in nature has been considered to be similar to that of mycorrhizal fungi $[46,47]$. These isolates will be analyzed in future studies. Among all isolates, the plant growth-promoting capacity of the only isolate from P. variotii was analyzed in this study.

Nevertheless, P. variotii was selected given the sparse literature on this species as a plant-growth promoter. The ability of $P$. variotii to stimulate plant growth is poorly studied, while for other species of the same genus, the growth-promoting effect is generally associated with an improvement in the plant status for its nematicide effect for the control of diseases caused by different nematode species [48].

A key requirement for selling microorganisms with a biostimulant capacity is that they have a high-spore production capacity in substrates with a low-production cost. Nevertheless, grains whose agitation leads to a rapid release of spores must be selected to obtain the formulation. For this reason, buckwheat husk and oats were selected for high performance in the spore production of $P$. variotii. This production occurred in the entire substrate, not only on the surface. Generally, commercial spore production methods often only use cereal grains, rice or other starch-based substrates [49]. The nutritional composition of the medium in which the growth promotor multiplies can affect its biocontrol or biostimulant capacity [50]. Based on our results, P. variotii can stimulate plant development under the production conditions described herein.

The $P$. variotii isolate has shown the ability to produce siderophores and IAA. Biostimulation is generally associated with increased nutrient availability, similar to biofertilization [51], but it is also caused by multiple other factors, such as mechanisms including enhancement of plant systemic resistance [52]. Thus, siderophore production plays a key role by enhancing the Fe uptake of plants and can be considered an ecofriendly alternative to the use of chemical fertilizers and pesticides in the agricultural sector [53]. Vala et al. [54] describe the production of both hydroxamate and carboxylate-type siderophores by $P$. variotii isolated from the surface of mangrove plants. Terrestrial $P$. variotii has previously been shown to secrete the trihydroxamate siderophore ferrirubin [55]. The P. variotii isolate has shown a relatively high IAA production in relation to its genus, and tryptophan incorporation slightly increased in vitro IAA biosynthesis by P. variotii. Other studies also reported that Trp considerably stimulated microbial IAA yield in vitro [56-58]. Ali [59] described IAA production by P. variotii lower than $2 \mathrm{ng} \mathrm{mL}^{-1}$ produced in Czapek medium supplemented with tryptophan. In our study, we described a much higher production for the same species. Waqas [60] described IAA 
production by $P$. formosus at $34.07 \pm 3.92 \mu \mathrm{g} \mathrm{mL}^{-1}$, a result very similar to the findings of this study, and consequently, a plant growth-promoting effect. Nevertheless, Waqas [61] analyzed the variability of IAA production as a function of the culture medium used and conversely found that $P$. variotii had virtually undetectable phosphatase activity. These results differed from the high phosphatase production by a P. variotii isolate from the medicinal plant Caralluma acutangula [59]. In soil, P-solubilizing fungi constitute approximately $0.1-0.5 \%$ of the total fungal population [62]. The use of microbial inoculants (biofertilizers) possessing P-solubilizing activities in crop productivity is considered as an alternative to further application of mineral P fertilizers [63]. Endophyte co-inoculation of plants exponentially improved the phosphatase activity of soil compared to that of the non-inoculated plants under stress conditions [64]. Etesami et al. [65] showed the relationship among ACC deaminase activity, IAA production, siderophore production and phosphate solubilization of bacterial strains and their effect on root elongation of rice seedlings. In this study, this correlation could not be determined since an isolate of P. variotii was analyzed.

The application of beneficial microorganisms (biopriming) may not only help to improve germination and vigor parameters but also relieve a wide range of physiological, abiotic and biotic stresses in both seeds and seedlings [66]. Nevertheless, biopriming can potentially lead to a more resistant plant after transplanting. This can depend on numerous factors, such as plant species, microorganisms, applied dose and substrates, among others. Thus, in this study, the P. variotii isolate enhanced germination and root vigor in tomato seeds. However, the results with pepper plants were different, with no significant differences from that of the controls and even with a $19.27 \%$ decrease in shoot length $(p<0.05)$. This may be because germination of pepper seeds is often more heterogeneous. Cochran [67] determined that the germination percentage and the accumulation of dry matter in the large seeds of bell pepper were higher in relation to the small seeds. P. variotii enhanced several tomato and pepper seedling parameters. The application doses for different crops must be studied for optimal outcomes. In this study, the application of a higher dose $\left(10^{6}\right.$ spores $\mathrm{mL}^{-1}$ versus $10^{5}$ spores $\left.\mathrm{mL}^{-1}\right)$ improved the different morphological parameters value in tomato seedlings under commercial plant nursery conditions. After transplanting in the greenhouse, the biostimulant effects persisted 4 months after applying the three doses without any additional application. Similar benefits have been observed as a result of the application of other species of the genus Paecilomyces. Waqas [68] described improved soybean seedling germination and SVI when applying the endophyte Paecilomyces sp. The application of $P$. variotii extracts significantly increased cherry radish yield, dry matter accumulation, the root-shoot ratio and quality. This extract has a very high biological activity, with a low cost, which has a great application prospect [69]. Similar studies conducted by Anis [70] showed increased sunflower seedling vigor under biotic stress conditions when applying P. variotii and Macrophomina phaseolina spores, in vitro, with no favorable results when conducting the tests in pots. In turn, Maitlo [71] assessed chickpea plant biostimulation when inoculating them with P. lilacinus and F. oxysporum f. sp. ciceris, which also reduced chickpea wilt.

In intensive horticulture under plastic, the benefits of the application of biostimulants or biofungicides based on microorganisms, are in question, because farmers perceive low efficacy of these products as disease controllers when compared with the rapid response presented by chemical fertilizers or fungicide. The current changes in legislation regarding the reduction of active ingredients and the commercialization of biostimulants and biopesticides, together with the need to increase the sustainability of agriculture in terms of public health and the environment, require the use of PPMs as a key element in horticulture.

To the best of our knowledge, the present study demonstrated for the first time the biostimulant capacity of $P$. variotii in pepper and tomato plants under commercial plant nursery and greenhouse conditions. 


\section{Patents}

This isolate was patented with a Spanish patent number ES2684858A1: New strain of Paecilomyces variotii, compositions and applications.

Author Contributions: F.D. and M.S. conceived and designed the experiments; A.M.-G. and B.S.-M. performed the experiments; F.D. analyzed the data; M.S. wrote the paper. All authors have read and agreed to the published version of the manuscript.

Funding: This research received no external funding.

Acknowledgments: The present work benefited from the input of the project RTC-2017-6486-2 was supported by the Spanish Ministry of Science, Innovation and Universities.

Conflicts of Interest: The authors declare that there is no conflict of interests regarding the publication of this manuscript.

\section{References}

1. Nguyen, T.T.T.; Paul, N.C.; Lee, H.B. Characterization of Paecilomyces variotii and Talaromyces amestolkiae in Korea Based on the Morphological Characteristics and Multigene Phylogenetic Analyses. Mycobiology 2016, 44, 248-259. [CrossRef] [PubMed]

2. Mioso, R.; Marante, F.J.T.; De Laguna, I.H.B. The Chemical Diversity of the Ascomycete Fungus Paecilomyces variotii. Appl. Biochem. Biotechnol. 2015, 177, 781-791. [CrossRef] [PubMed]

3. De Laguna, I.H.B.; Marante, F.J.T.; Mioso, R. Enzymes and bioproducts produced by the ascomycete fungus Paecilomyces variotii. J. Appl. Microbiol. 2015, 119, 1455-1466. [CrossRef] [PubMed]

4. Akinfala, T.O.; Houbraken, J.; Sulyok, M.; Adedeji, A.R.; Odebode, A.C.; Krska, R.; Ezekiel, C.N. Moulds and their secondary metabolites associated with the fermentation and storage of two cocoa bean hybrids in Nigeria. Int. J. Food Microbiol. 2020, 316, 108490. [CrossRef] [PubMed]

5. Lòpez-Fernàndez, S.; Campisano, A.; Schulz, B.J.; Steinert, M.; Stadler, M.; Surup, F. Viriditins from Byssochlamys spectabilis, their stereochemistry and biosynthesis. Tetrahedron Lett. 2020, 61, 151446. [CrossRef]

6. Al-Qasim, M.; Abu-Gharbieh, W.; Assas, K. Nematophagal ability of Jordanian isolates of Paecilomyces variotii on the root-knot nematode Meloidogyne javanica. Nematol. Mediterr. 2009, 37, 53-57.

7. Perveen, Z.; Shahzad, S. A comparative study of the efficacy of Paecilomyces species against root-knot nematode Meloidogyne incognita. Pak. J. Nematol. 2013, 31, 125-135.

8. Ahmad, R.Z.; Sidi, B.B.; Endrawati, D.; Ekawasti, F. Paecilomyces lilacinus and P. variotii as a predator of nematode and trematode eggs. IOP Conf. Ser. Earth Environ. Sci. 2019, 299, 012056. [CrossRef]

9. Rodrigo, S.; Santamaria, O.; Halecker, S.; Lledó, S.; Stadler, M. Antagonism betweenByssochlamys spectabilis(anamorphPaecilomyces variotii) and plant pathogens: Involvement of the bioactive compounds produced by the endophyte. Ann. Appl. Boil. 2017, 171, 464-476. [CrossRef]

10. Mohammadi, S.; Soltani, J.; Piri, K. Soilborne and invertebrate pathogenic Paecilomyces species show activity against pathogenic fungi and bacteria. J. Crop. Prot. 2016, 5, 377-387. [CrossRef]

11. Zhang, P.; Li, X.M.; Wang, J.N.; Wang, B.G. Oxepine-containing diketopiperazine alkaloids from the algal-derived endophytic fungus Paecilomyces variotii EN-291. Helv. Chim. Acta 2015, 98, 800-804. [CrossRef]

12. Hajano, J.U.D.; Lodhi, M.; Pathan, M.A.; Khanzada, A.; Shah, G.S. In-vitro evaluation of fungicides, plant extracts and bio-control agents against rice blast pathogen Magnaporthe oryzae couch. Pak. J. Bot. 2012, 44, 1775-1778.

13. Nakajima, M.; Itoi, K.; Takamatsu, Y.; Sato, S.; Furukawa, Y.; Furuya, K.; Honma, T.; Kadotani, J.; Kozasa, M.; Haneishi, T. Cornexistin: A new fungal metabolite with herbicidal activity. J. Antibiot. 1991, 44, 1065-1072. [CrossRef]

14. Song, X.; Zhang, L.H.; Peng, A.T.; Cheng, B.P.; Ling, J.F. First Report of Paecilomyces variotii Isolated From Citrus Psyllid (Diaphorina citri), the Vector of Huanglongbing of Citrus, in China. Plant Dis. 2016, 100, 2526. [CrossRef]

15. Hyung, J.J.; Kang, H.; Jong, J.J.; Soo, K.Y. Paecilomyces Variotii Extracts for Preventing and Treating Infections Caused by Fish Pathogenic Microorganisms. KR Patent 2013051523, 2013. 
16. García-Peña, E.; Hernández, S.; Auria, R.; Revah, S. Correlation of Biological Activity and Reactor Performance in Biofiltration of Toluene with the Fungus Paecilomyces variotii CBS115145. Appl. Environ. Microbiol. 2005, 71, 4280-4285. [CrossRef]

17. García-Peña, E.; Ortiz, I.; Hernandez, S.; Revah, S. Biofiltration of BTEX by the fungus Paecilomyces variotii. Int. Biodeterior. Biodegrad. 2008, 62, 442-447. [CrossRef]

18. Liu, Z.; Liu, G.; Cai, H.; Shi, P.; Chang, W.; Zhang, S.; Zheng, A.; Xie, Q.; Ma, J. Paecilomyces variotii: A Fungus Capable of Removing Ammonia Nitrogen and Inhibiting Ammonia Emission from Manure. PLoS ONE 2016, 11, e0158089. [CrossRef]

19. Steiner, B.; Aquino, V.R.; Paz, A.A.; Silla, L.M.D.R.; Zavascki, A.; Goldani, L. Paecilomyces variotii as an Emergent Pathogenic Agent of Pneumonia. Case Rep. Infect. Dis. 2013, 2013, 1-3. [CrossRef]

20. Santamaria, O.; Lledó, S.; Rodrigo, S.; Poblaciones, M.J. Effect of Fungal Endophytes on Biomass Yield, Nutritive Value and Accumulation of Minerals in Ornithopus compressus. Microb. Ecol. 2017, 74, 841-852. [CrossRef]

21. Lu, C.; Liu, H.; Jiang, D.; Wang, L.; Jiang, Y.; Tang, S.; Hou, X.; Han, X.; Liu, Z.; Zhang, M.; et al. Paecilomyces variotii extracts (ZNC) enhance plant immunity and promote plant growth. Plant Soil 2019, 441, 383-397. [CrossRef]

22. Sánchez-Montesinos, B.; Diánez, F.; Moreno-Gavíra, A.; Gea, F.J.; Santos, M. Plant Growth Promotion and Biocontrol of Pythium ultimum by Saline Tolerant Trichoderma Isolates under Salinity Stress. Int. J. Environ. Res. Public Health 2019, 16, 2053. [CrossRef]

23. Raja, N. Biopesticides and Biofertilizers: Ecofriendly Sources for Sustainable Agriculture. J. Fertil. Pestic. 2013, 4, e112. [CrossRef]

24. Adesemoye, A.; Kloepper, J.W. Plant-microbes interactions in enhanced fertilizer-use efficiency. Appl. Microbiol. Biotechnol. 2009, 85, 1-12. [CrossRef] [PubMed]

25. Vandenberghe, L.; Garcia, L.M.B.; Rodrigues, C.; Camara, M.C.; Pereira, G.; De Oliveira, J.; Soccol, C.R. Potential applications of plant probiotic microorganisms in agriculture and forestry. AIMS Microbiol. 2017, 3, 629-648. [CrossRef]

26. Martínez, F.D.; Santos, M.; Carretero, F.; Marin, F. Trichoderma saturnisporum,a new biological control agent. J. Sci. Food Agric. 2015, 96, 1934-1944. [CrossRef]

27. Fernando, D.; Santos, M.; Francisco, C.; Francisco, M. Biostimulant Activity of Trichoderma saturnisporum in Melon (Cucumis melo). HortScience 2018, 53, 810-815. [CrossRef]

28. Smith, S.E.; Manjarrez, M.; Stonor, R.; McNeill, A.; Smith, F.A. Indigenous arbuscular mycorrhizal (AM) fungi contribute to wheat phosphate uptake in a semi-arid field environment, shown by tracking with radioactive phosphorus. Appl. Soil Ecol. 2015, 96, 68-74. [CrossRef]

29. Bhardwaj, D.; Ansari, M.; Sahoo, R.K.; Tuteja, N. Biofertilizers function as key player in sustainable agriculture by improving soil fertility, plant tolerance and crop productivity. Microb. Cell Factories 2014, 13, 66. [CrossRef]

30. Begum, N.; Qin, C.; Ahanger, M.A.; Raza, S.; Khan, M.I.; Ashraf, M.; Ahmed, N.; Zhang, L. Role of Arbuscular Mycorrhizal Fungi in Plant Growth Regulation: Implications in Abiotic Stress Tolerance. Front. Plant Sci. 2019, 10, 1068. [CrossRef]

31. Khan, M.R.; Mohiddin, F.A. Trichoderma: Its Multifarious Utility in Crop Improvement. In Crop Improvement through Microbial Biotechnology; Elsevier BV: Amsterdam, The Netherlands, 2018; pp. 263-291.

32. Murali, M.; Amruthesh, K.N. Plant Growth-promoting Fungus Penicillium oxalicum Enhances Plant Growth and Induces Resistance in Pearl Millet Against Downy Mildew Disease. J. Phytopathol. 2015, 163, 743-754. [CrossRef]

33. Shimizu, K.; Hossain, M.M.; Kato, K.; Kubota, M.; Hyakumachi, M. Induction of Defense Responses in Cucumber Plants by Using the Cell-free Filtrate of the Plant Growth-Promoting Fungus Penicillium simplicissimum GP17-2. J. Oleo Sci. 2013, 62, 613-621. [CrossRef] [PubMed]

34. Bitas, V.; McCartney, N.; Li, N.; Demers, J.; Kim, J.-E.; Kim, H.-S.; Brown, K.M.; Kang, S. Fusarium Oxysporum Volatiles Enhance Plant Growth Via Affecting Auxin Transport and Signaling. Front. Microbiol. 2015, 6, 351. [CrossRef] [PubMed]

35. Kojima, H.; Hossain, M.; Kubota, M.; Hyakumachi, M. Involvement of the salicylic acid signaling pathway in the systemic resistance induced in Arabidopsis by plant growth-promoting fungus Fusarium equiseti GF19-1. J. Oleo Sci. 2013, 62, 415-426. [CrossRef] [PubMed] 
36. Zhou, L.S.; Tang, K.; Guo, S.-X. The Plant Growth-Promoting Fungus (PGPF) Alternaria sp. A13 Markedly Enhances Salvia miltiorrhiza Root Growth and Active Ingredient Accumulation under Greenhouse and Field Conditions. Int. J. Mol. Sci. 2018, 19, 270. [CrossRef]

37. Islam, S.; Akanda, A.M.; Sultana, F.; Hossain, M. Chilli rhizosphere fungus Aspergillus spp. PPA1 promotes vegetative growth of cucumber (Cucumis sativus) plants upon root colonisation. Arch. Phytopathol. Plant Prot. 2013, 47, 1231-1238. [CrossRef]

38. Naznin, H.A.; Kimura, M.; Miyazawa, M.; Hyakumachi, M. Analysis of Volatile Organic Compounds Emitted by Plant Growth-Promoting Fungus Phoma sp. GS8-3 for Growth Promotion Effects on Tobacco. Microbes Environ. 2012, 28, 42-49. [CrossRef]

39. Schwyn, B.; Neilands, J. Universal chemical assay for the detection and determination of siderophores. Anal. Biochem. 1987, 160, 47-56. [CrossRef]

40. Louden, B.C.; Haarmann, D.; Lynne, A.M. Use of Blue Agar CAS Assay for Siderophore Detection. J. Microbiol. Boil. Educ. 2011, 12, 51-53. [CrossRef]

41. Nautiyal, C.S. An efficient microbiological growth medium for screening phosphate solubilizing microorganisms. FEMS Microbiol. Lett. 1999, 170, 265-270. [CrossRef]

42. Lima-Rivera, D.L.; Lopez-Lima, D.; Desgarennes, D.; Velázquez-Rodríguez, A.S.; Carrión, G. Phosphate solubilization by fungi with nematicidal potential. J. Soil Sci. Plant Nutr. 2016, 16, 507-524. [CrossRef]

43. Fiske, C.H.; Subbarow, Y. The colorimetry determination of phosphorous. J. Biol. Chem. 1925, 66, 375-400.

44. Murali, M.; Amruthesh, K.N.; Sudisha, J.S.; Niranjana, R.; Shetty, H.S. Screening for plant growth promoting fungi and their ability for growth promotion and induction of resistance in pearl millet against downy mildew disease. J. Phytol. 2012, 4, 30-36.

45. Dickson, A.; Leaf, A.L.; Hosner, J.F. Quality Appraisal of White Spruce and White Pine Seedling Stock in Nurseries. For. Chron. 1960, 36, 10-13. [CrossRef]

46. Peterson, R.L.; Wagg, C.; Pautler, M. Associations between microfungal endophytes and roots: Do structural features indicate function? Botany 2008, 86, 445-456. [CrossRef]

47. Della Mónica, I.F.; Saparrat, M.C.; Godeas, A.M.; Scervino, J.M. The co-existence between DSE and AMF symbionts affects plant P pools through P mineralization and solubilization processes. Fungal Ecol. 2015, 17, 10-17. [CrossRef]

48. Huang, W.-K.; Cui, J.-K.; Liu, S.-M.; Kong, L.-A.; Wu, Q.-S.; Peng, H.; He, W.-T.; Sun, J.-H.; Peng, D.-L. Testing various biocontrol agents against the root-knot nematode (Meloidogyne incognita) in cucumber plants identifies a combination of Syncephalastrum racemosum and Paecilomyces lilacinus as being most effective. Boil. Control. 2016, 92, 31-37. [CrossRef]

49. Goettel, M.S.; Roberts, D.W. Mass production, formulation and field application of entomopathogenic fungi. In Biological Control of Locusts and Grasshopper; Lomer, C.J., Prior, C., Eds.; CAB International: Wallingford, UK, 1992.

50. Lane, B.S.; Trinci, A.P.; Gillespie, A.T. Influence of cultural conditions on the virulence of conidia and blastospores of Beauveria bassiana to the green leafhopper, Nephotettix virescens. Mycol. Res. 1991, 95, 829-833. [CrossRef]

51. Vessey, J.K. Plant growth promoting rhizobacteria as biofertilizers. Plant Soil 2003, 255, 571-586. [CrossRef]

52. Schuster, A.; Schmoll, M. Biology and biotechnology of Trichoderma. Appl. Microbiol. Biotechnol. 2010, 87, 787-799. [CrossRef]

53. Saha, M.; Sarkar, S.; Sarkar, B.; Sharma, B.K.; Bhattacharjee, S.; Tribedi, P. Microbial siderophores and their potential applications: A review. Environ. Sci. Pollut. Res. 2015, 23, 3984-3999. [CrossRef] [PubMed]

54. Vala, A.K.; Vaidya, S.Y.; Dube, H.C. Siderophore production by facultative marine fungi. Indian J. Mar. Sci. 2000, 29, 339-340.

55. Renshaw, J.C.; Robson, G.; Trinci, A.P.; Wiebe, M.; Livens, F.R.; Collison, D.; Taylor, R. Fungal siderophores: Structures, functions and applications. Mycol. Res. 2002, 106, 1123-1142. [CrossRef]

56. Ivanova, E.G.; Doronina, N.V.; Trotsenko, Y.A. Aerobic Methylobacteria Are Capable of Synthesizing Auxins. Microbiology 2001, 70, 392-397. [CrossRef]

57. Khalid, A.; Arshad, M.; Zahir, Z. Screening plant growth-promoting rhizobacteria for improving growth and yield of wheat. J. Appl. Microbiol. 2004, 96, 473-480. [CrossRef] [PubMed]

58. Egamberdieva, D.; Kucharova, Z. Selection for root colonizing bacteria stimulating wheat growth in saline soils. Biol. Fertil. Soil 2009, 45, 563-571. [CrossRef] 
59. Ali, S. Endophytic fungi from Caralluma acutangula can secrete plant growth promoting enzymes. Fresenius Environ. Bull. 2019, 28, 2688-2696.

60. Waqas, M.; Khan, A.L.; Shahzad, R.; Ullah, I.; Khan, A.R.; Lee, I.-J. Mutualistic fungal endophytes produce phytohormones and organic acids that promote japonica rice plant growth under prolonged heat stress* ${ }^{*}$. Zhejiang Univ. Sci. B 2015, 16, 1011-1018. [CrossRef]

61. Waqas, M.; Khan, A.L.; Lee, I.-J. Bioactive chemical constituents produced by endophytes and effects on rice plant growth. J. Plant Interact. 2013, 9, 478-487. [CrossRef]

62. Kucey, R.M.N. Effect of Penicillium bilaji on the Solubility and Uptake of P and Micronutrients from Soil by Wheat. Can. J. Soil Sci. 1988, 68, 261-270. [CrossRef]

63. Khan, M.S.; Zaidi, A.; Ahemad, M.; Oves, M.; Wani, P.A. Plant growth promotion by phosphate solubilizing fungi-current perspective. Arch. Agron. Soil Sci. 2010, 56, 73-98. [CrossRef]

64. Bilal, S.; Shahzad, R.; Khan, A.L.; Kang, S.-M.; Imran, Q.M.; Al-Harrasi, A.; Yun, B.-W.; Lee, I.-J. Endophytic Microbial Consortia of Phytohormones-Producing Fungus Paecilomyces formosus LHL10 and Bacteria Sphingomonas sp. LK11 to Glycine max L. Regulates Physio-hormonal Changes to Attenuate Aluminum and Zinc Stresses. Front. Plant Sci. 2018, 9. [CrossRef] [PubMed]

65. Etesami, H.; Alikhani, H.A.; Hosseini, H.M. Indole-3-acetic acid (IAA) production trait, a useful screening to select endophytic and rhizosphere competent bacteria for rice growth promoting agents. MethodsX 2015, 2, 72-78. [CrossRef] [PubMed]

66. Mastouri, F.; Björkman, T.; Harman, G.E. Seed Treatment withTrichoderma harzianumAlleviates Biotic, Abiotic, and Physiological Stresses in Germinating Seeds and Seedlings. Phytopathology 2010, 100, 1213-1221. [CrossRef]

67. Cochran, H.C. Effect of seed size on uniformity of pimento transplants (Capsicum annuum L.) at harvest time. J. Am. Sot. Hort. Sci. 1974, 99, 234-235.

68. Waqas, M.; Khan, A.L.; Hamayun, M.; Kamran, M.; Kang, S.M.; Kim, Y.H.; Lee, I.J. Assessment of endophytic fungi cultural filtrate on soybean seed germination. Afr. J. Biotechnol. 2012, 11, 15135-15143.

69. Jia, C.; Liu, Z.; Zhang, M.; Jia, J.; Zheng, L.; Wang, Q.; Wang, H. Effects of extracts from Paecilomyces variotii on the yield and quality of cherry radish (Raphanus sativus L. var. radculus pers). J. Agric. Res. Environ. 2019, 36, 176-183.

70. Anis, M.; Abbasi, W.; Zaki, M.J. Bioefficacy of microbial antagonists against Macrophomina phaseolina on sunflower. Pak. J. Bot. 2010, 42, 2935-2940.

71. Maitlo, S.A.; Rajput, N.A.; Syed, R.N.; Khanzada, M.A.; Rajput, A.Q.; Lodhi, A.M. Microbial control of Fusarium wilt of chickpea caused by Fusarium oxysporum f. sp. ciceris. Pak. J. Bot. 2019, 51, 2261-2268. [CrossRef]

(C) 2020 by the authors. Licensee MDPI, Basel, Switzerland. This article is an open access article distributed under the terms and conditions of the Creative Commons Attribution (CC BY) license (http://creativecommons.org/licenses/by/4.0/). 